\title{
Comparative Analysis of Community Acquired Methicillin-resistant Staphylococcus aureus Nasal Carriage in Eastern Province of Saudi Arabia
}

\author{
Baraa A Amir ${ }^{1}$, Ali A Rabaan ${ }^{2-4}$ and Salwa S Sheikh ${ }^{5 *}$ \\ ${ }^{1}$ College of Medicine, Imam Abdulrahman Bin Faisal University, Dammam, Saudi \\ Arabia \\ ${ }^{2}$ Molecular Diagnostic Laboratory, Johns Hopkins Aramco Healthcare, Dhahran, \\ Saudi Arabia \\ ${ }^{3}$ College of Medicine, Alfaisal University, Riyadh, Saudi Arabia \\ ${ }^{4}$ Department of Public Health and Nutrition, The University of Haripur, Haripur, \\ Pakistan \\ ${ }^{5}$ Pathology Services Division, Johns Hopkins Aramco Healthcare, Dhahran, Saudi \\ Arabia \\ *Corresponding Author: Salwa S Sheikh, Pathology Services Division, Johns \\ Hopkins Aramco Healthcare, Dhahran, Saudi Arabia.
}

Received: November 30, 2021

Published: December 27, 2021

(C) All rights are reserved by Salwa S Sheikh., et al.

\begin{abstract}
Background: The purpose of this study was to investigate community-associated methicillin-resistant Staphylococcus aureus (CAMRSA) nasal carriage rates among outpatients attending a hospital in the Eastern Province of Saudi Arabia. Additionally, this study involved a literature review for comparison of data between different parts of Saudi Arabia and of the Saudi average to the USA and other countries.

Methods: Duplicate nasal swabs from 3188 outpatients attending Johns Hopkins Aramco Healthcare Center in Dhahran in the Eastern Province of Saudi Arabia between January 2013 and December 2014 were tested using Xpert MRSA-SA Nasal Complete G3 kits (Cepheid). A literature review was also conducted using Pubmed, Google Scholar, and Cochrane Library regarding MRSA nasal carrier status.

Results: Nine hundred and thirty-one patients (29.2\%) were nasal S. aureus carriers, of which 121 (3.8\% overall; $13 \%$ of S. aureus carriers) were colonized by CA-MRSA. Our measured CA-MRSA levels were lower than those observed in smaller studies from northcentral or central Saudi Arabia, but comparable to levels observed among pediatric outpatients from Riyadh.

Conclusion: Overall Saudi levels were higher than for countries including the United States and European countries. Targeted public health strategies to address CA-MRSA levels in Saudi Arabia are indicated.
\end{abstract}

Keywords: CA-MRSA; Saudi Arabia; Staphylococcus aureus; Xpert MRSA-SA Nasal Complete

\section{Introduction}

Methicillin-resistant Staphylococcus aureus (MRSA) can cause illnesses in humans ranging in severity from mild to life-threatening. It is more arduous to treat than other Staphylococcus aureus strains because of its resistance to semi-synthetic penicillin such as methicillin, nafcillin, and oxacillin [1]. MRSA can be acquired in hospitals and other healthcare facilities (healthcare-associated MRSA; HA-MRSA) and from the community (community-associated 
MRSA; CA-MRSA). Globally, CA-MRSA has emerged as a significant public health threat, arising in previously healthy individuals in the community without established healthcare-associated risk factors. It is typically associated with skin and soft tissue infections (SSTIs) arising in the community; for example, in patients presenting to emergency departments (EDs) in the United States of America (USA), CA-MRSA is the leading cause of SSTIs. According to the CDC definition, CA-MRSA is diagnosed if MRSA is observed in an outpatient or in an individual within 48 hours of hospitalization and when risk factors outlined for HA-MRSA are lacking [2]. However, conventional definitions have been challenged by changing epidemiology, with for example emergence of CA-MRSA in healthcare settings. Genotypically, a major difference between HA-MRSA and CA-MRSA is the Staphylococcal cassette chromosome (SCCmec) expressed; SCCmec types I, II and III are generally associated with HA-MRSA while types IV and V are associated with CA-MRSA. Most circulating MRSA strains are either SCCmec II or IV [3]. The predominant circulating strains of CA-MRSA vary between and within countries; while pulsed-field type USA300 predominates in the USA, it is uncommon in other countries, for example in Europe where individual countries have their own heterogenous molecular epidemiologies distinct from other European countries [4].

While many HA-MRSA studies have been conducted in Saudi Arabia, the same cannot be said regarding CA-MRSA, especially in the Eastern Province. Currently, there are no studies on occurrence and prevalence of CA-MRSA that draw data from large sample sizes in the Eastern Province of Saudi Arabia. Therefore, it is of the utmost importance to find more accurate data by analyzing a bigger sample size. Insights into CA-MRSA colonization patterns in Saudi Arabia would help inform detection, prevention and control strategies. The goal of this study was to investigate the prevalence of CAMRSA nasal carriage among community members in the Eastern Province of Saudi Arabia when they were attending as outpatients for other health-related issues. In addition, this study involved conducting a literature review comparing data from different parts of Saudi Arabia and comparison of the Saudi average to the USA, as it is considered to be the benchmark of MRSA research across the world, and to other countries.

\section{Methods}

Study population

Duplicate nasal swabs were collected in advance from 3188 outpatients attending Johns Hopkins Aramco Healthcare Center
(JHAH) in Dhahran in the Eastern province of Saudi Arabia between January 2013 and December 2014 as part of a quality control program in the hospital. This program was also followed by most other hospitals in the region in that time period as part of an active surveillance program, due to rising numbers of people being admitted to hospitals in Saudi Arabia with MRSA. The work was carried out in accordance with the Declaration of Helsinki.

\section{PCR assay}

All the samples were tested using Xpert MRSA-SA Nasal Complete G3 kits (Cepheid), which are based on multiplex, real-time PCR to detect proprietary sequences for the Staphylococcus protein A (spa) gene, the methicillin/oxacillin resistance gene ( $m e c A)$, and the staphylococcal cassette chromosome (SCCmec) inserted into the SA chromosomal attB site. This allows simultaneous detection of spa, to confirm the presence of $S$. aureus, and of mecA and the SCCmec/orfX junction to confirm the presence of MRSA. The basic sample preparation and PCR procedures were carried out according to the manufacturer's instructions, as described previously [5] PCRs were performed on the GeneXpert Dx System and results were obtained by measuring fluorescent signals and using embedded calculation algorithms. A Sample Processing Control (SPC) was included for each run to check that samples were correctly processed and that any $S$. aureus present was lysed efficiently, and for any specimen-associated inhibition of the real-time PCR assay. A Probe Check Control (PCC) was also included to check bead rehydration, reaction tube filling, integrity of the probe and stability of the fluorophore [5]. Results were recorded as NM0 (negative for CA-MRSA and S. aureus), NM8 (negative for CA-MRSA, positive for $S$. aureus) or PM0 (CA-MRSA positive), Invalid (presence or absence of MRSA cannot be verified; SPC failed; test should be repeated with the duplicate swab or alternative test performed), Error (presence or absence of MRSA cannot be verified; PCC failed; test aborted and should be repeated with the duplicate swab or alternative test performed) or No Result (insufficient data collected, e.g. stopping a test in progress). Nasal S. aureus and CA-MRSA carrier status in JHAH hospital outpatients were determined from the data.

\section{Literature Review}

A literature review was conducted using Pubmed, Google Scholar, and Cochrane Library regarding MRSA nasal carrier status among outpatients and patients upon admission to healthcare facilities in Saudi Arabia and its regions for local comparison using 
combinations of keywords including 'community acquired', 'MRSA', 'nasal', 'nares', 'patients', 'outpatients' for studies carried out in the last ten years. A corresponding literature review was done for other continents and countries including the United States of America (USA), Europe, Australia and Asia in the last ten years for comparison with the Saudi Arabia findings and data. CA-MRSA nasal carrier rates in Saudi Arabia were compared with rates from other countries in order to assess the extent of geographic variability. From the data obtained, multiple comparative graphs were compiled.

\section{Results}

A total of 3188 outpatients were screened for CA-MRSA/S. aureus carriage. Nine hundred and thirty-one patients (29.2\%) were nasal S. aureus carriers (NM8 or PM0). Of these, 810 patients were nasal S. aureus carriers but not CA-MRSA carriers (NM8), of which 796 (98.3\%) were Saudi. One hundred and twenty-one patients (3.8\% overall) were colonized by CA-MRSA (PM0), of which 120 (99.2\%) were Saudi. Thus, the average fraction of CA-MRSA among all S. aureus carriers was $13 \%$ (121 out of 931).

Male to female ratio for $S$. aureus colonization was 503:307 (62.1\% male, $37.9 \%$ female), while male to female ratio for CAMRSA was 62:59 (51.2\% male, 48.8\% female) (Figure 1). Outpatients with NM8 status were therefore significantly more likely to be male than female, whereas there was no significant difference in PM0 status between males and females (Figure 1; Chi-square statistic $=5.2033 ; \mathrm{p}=0.022544$ comparing gender distribution of NM8 versus PM0). There was no significant variation in distribution between PM0 and NM8 status according to age group of outpatients (Chi-square statistic $=4.9539 ; \mathrm{p}=0.292$ ).

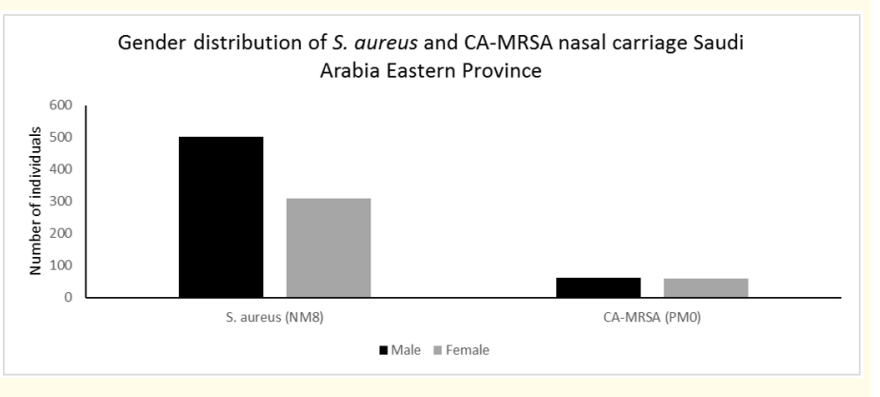

Figure 1: Gender distribution of S. aureus and MRSA nasal carrier rates.
Based on our data gathered from the nasal swab tests, the overall carrier rate of CA-MRSA in Dhahran (JHAH) in the Eastern Province of Saudi Arabia was calculated to be 3.8\%, while the percentage of $S$. aureus samples which were positive for MRSA was $13 \%$. Literature analysis was carried out to identify studies on CA-MRSA prevalence in Saudi Arabia within the last ten years, and nine studies were identified (Table 1) [6-14]. Studies in which nasal carriage was specifically addressed and in which CA-MRSA overall carriage rates (as opposed to only as a percentage of $S$. aureus) could be inferred were limited to five in this time period (Table 1) [6-8,12, 13]. Three of these studies were performed on hospital outpatients or patients within $48 \mathrm{~h}$ of hospital admission [6-8]. For these three studies, nasal carriage rate of CA-MRSA in outpatients or patients upon hospital admission ranged from $4.6 \%$ in Riyadh $23.2 \%$ of S. aureus-positive samples), to $21.8 \%$ in Shaqra in central Saudi Arabia (53.3\% of S. aureus samples) (Figure 2) [6-8]. Therefore, the mean nasal carrier rate of CA-MRSA among outpatients and patients upon hospital admission in Saudi Arabia based on the data collected from our study and from the literature is $13.9 \pm$ $9.7 \%$ (mean $\pm \mathrm{SD}$ ). The mean $S$. aureus nasal carriage rate is 34.6 $\pm 11.0 \%$. The mean proportion of $S$. aureus infections that are CAMRSA among these patients is $35.4 \pm 17.7 \%$. The distribution of CA-MRSA carriage both overall and as a proportion of $S$. aureus that can be calculated for outpatients and patients upon hospital admission from these studies is summarized in figure 2 .

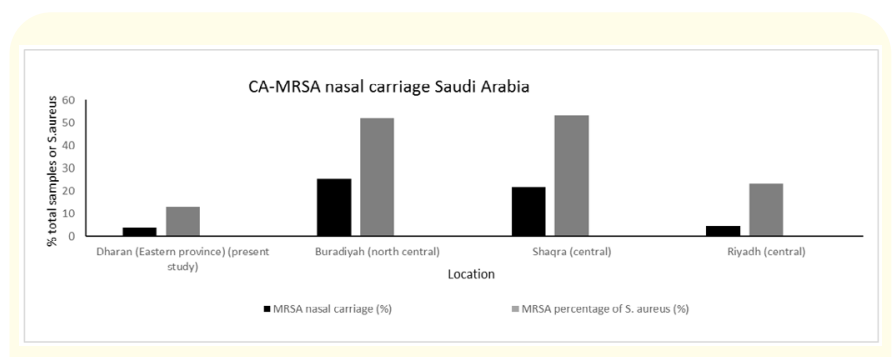

Figure 2: CA-MRSA nasal carriage rates in Saudi Arabia.

The two other studies were carried out on medical students; a nasal CA-MRSA carriage rate of $1.0 \%$ was observed for Riyadh, while a $0 \%$ rate was observed in Jeddah (western Saudi Arabia) in the absence of clinical exposure [16,17]. In the Jeddah study, the carriage rate was $6.7 \%$ for medical students with clinical exposure, but in this case CA-MRSA cannot be inferred versus HA-MRSA [17]. 


\begin{tabular}{|c|c|c|c|c|c|c|c|}
\hline Place & Time period & Patient and sample type & Sample size & $\begin{array}{l}\text { S. aureus car- } \\
\text { riage }\end{array}$ & $\begin{array}{l}\text { MRSA carriage } \\
\text { overall }\end{array}$ & $\begin{array}{l}\text { MRSA as propor- } \\
\text { tion of } S \text {. aureus }\end{array}$ & Reference \\
\hline \multicolumn{8}{|l|}{ Saudi Arabia } \\
\hline $\begin{array}{l}\text { Buradiyah City } \\
\text { (north-central } \\
\text { Saudi Arabia) }\end{array}$ & $\begin{array}{l}\text { July-October } \\
2011\end{array}$ & $\begin{array}{l}\text { Primary care centre outpatients } \\
\text { Nasal samples }\end{array}$ & 103 & $48.5 \%$ & $25.2 \%$ & $52 \%$ & $\begin{array}{l}\text { Abou-Shady., } \\
\text { et al. } 2015\end{array}$ \\
\hline $\begin{array}{l}\text { Shaqra (central } \\
\text { Saudi Arabia) }\end{array}$ & $\begin{array}{l}\text { October 2014- } \\
\text { March } 2015 \\
\end{array}$ & $\begin{array}{l}\text { Patients within } 48 \mathrm{~h} \text { of hospital admission } \\
\text { Nasal samples }\end{array}$ & 220 & $40.9 \%$ & $21.8 \%$ & $53.3 \%$ & $\begin{array}{l}\text { Alhuassaini., } \\
\text { et al. } 2016\end{array}$ \\
\hline $\begin{array}{l}\text { Riyadh (central } \\
\text { Saudi Arabia) }\end{array}$ & March-July 2015 & $\begin{array}{l}\text { Outpatients (pediatric) } \\
\text { Nasal samples }\end{array}$ & 830 & $19.8 \%$ & $4.6 \%$ & $23.2 \%$ & $\begin{array}{l}\text { Alaklobi., } \text { et } \\
\text { al. } 2015\end{array}$ \\
\hline Riyadh & $\begin{array}{l}\text { December 2013- } \\
\quad \text { April } 2014\end{array}$ & $\begin{array}{l}\text { Medical students } \\
\text { Nasal samples }\end{array}$ & 97 & $33 \%$ & $1.0 \%$ & $3.1 \%$ & $\begin{array}{l}\text { Sarkar., et al. } \\
\quad 2016\end{array}$ \\
\hline $\begin{array}{l}\text { Makkah City } \\
\text { (western Saudi } \\
\text { Arabia) }\end{array}$ & $\begin{array}{l}\text { November } \\
\text { 2009-October } \\
2010\end{array}$ & $\begin{array}{l}\text { Community and hospitalised patients } \\
\text { from single hospital } \\
\text { All clinical isolates expressing S. aureus } \\
\text { (mainly wound, SSTI) }\end{array}$ & $\begin{array}{l}\text { Community: } 124 \\
\text { Hospitalised:: } 76\end{array}$ & Not applicable & Not determined & $\begin{array}{l}\text { CA-MRSA: } 31.5 \% \\
\text { HA-MRSA: } 52.6 \%\end{array}$ & $\begin{array}{l}\text { El-Amin., et } \\
\text { al. } 2012\end{array}$ \\
\hline Makkah City & $\begin{array}{l}\text { March-September } \\
2012\end{array}$ & $\begin{array}{l}\text { Participant profile not specified (clinical } \\
\text { isolates from } 5 \text { hospitals) } \\
\text { All clinical isolates expressing S. aureus }\end{array}$ & 206 & Not applicable & Not determined & $\begin{array}{l}\text { CA-MRSA: } 14.1 \% \\
\text { HA-MRSA: } 34.5 \%\end{array}$ & $\begin{array}{l}\text { Ashgar., et al. } \\
\quad 2014\end{array}$ \\
\hline $\begin{array}{l}\text { Jeddah (western } \\
\text { Saudi Arabia) }\end{array}$ & Not specified & $\begin{array}{l}\text { Participant profile not specified (clinical } \\
\text { isolates from KAUH clinical microbiology) } \\
\text { All clinical isolates expressing S. aureus }\end{array}$ & 89 & Not applicable & Not determined & $\begin{array}{l}\text { CA-MRSA: } 34.8 \% \\
\text { HA-MRSA: } 7.9 \%\end{array}$ & $\begin{array}{l}\text { Al-Zahrani., } \\
\text { et al. } 2018\end{array}$ \\
\hline Jeddah & $\begin{array}{l}\text { September } \\
\text { 2014-January } \\
2015\end{array}$ & $\begin{array}{l}\text { Medical students: } \\
\text { Clinical exposure and non-clinical expo- } \\
\text { sure } \\
\text { Nasal samples }\end{array}$ & $\begin{array}{l}\text { Clinical expo- } \\
\text { sure: } 150 \\
\text { non-clinical expo- } \\
\text { sure: } 32\end{array}$ & $25.3 \%$ & \begin{tabular}{|c|}
$6.7 \%$ (clinical \\
exposure group) \\
0 (non-clinical \\
exposure group)
\end{tabular} & $\begin{array}{c}26.3 \% \text { (clinical } \\
\text { exposure group; } \\
\text { HA-MRSA or CA- } \\
\text { MRSA status not } \\
\text { specified)) }\end{array}$ & Zakai, 2015 \\
\hline $\begin{array}{l}\text { Taif (southwest } \\
\text { Saudi Arabia; } \\
\text { Mecca province) }\end{array}$ & $\begin{array}{c}\text { January } \\
\text { 2013-February } \\
2015 \\
\end{array}$ & $\begin{array}{l}\text { Participant profile not specified } \\
\text { All clinical isolates expressing } S \text {. aureus }\end{array}$ & 445 & Not applicable & Not determined & $\begin{array}{l}\text { CA-MRSA: } 5.8 \% \\
\text { HA-MRSA: } 10.1 \%\end{array}$ & $\begin{array}{l}\text { Eed., et al. } \\
\quad 2016\end{array}$ \\
\hline \multicolumn{8}{|l|}{ Other countries } \\
\hline $\begin{array}{l}\text { United States } \\
\text { (Colorado) }\end{array}$ & $\begin{array}{c}\text { October } \\
\text { 2007-September } \\
2013\end{array}$ & $\begin{array}{c}\text { Patients on admission to tertiary medical } \\
\text { centre } \\
\text { Nasal samples }\end{array}$ & 29371 & Not specified & 11.1 & Not specified & $\begin{array}{l}\text { Marzec., et al. } \\
\quad 2016\end{array}$ \\
\hline $\begin{array}{l}\text { United States } \\
\text { (Boston) }\end{array}$ & $\begin{array}{l}\text { June 2009-May } \\
2010\end{array}$ & $\begin{array}{l}\text { ED patients on admission } \\
\text { Nasal samples }\end{array}$ & 400 & $25.3 \%$ & $2.8 \%$ & $10.9 \%$ & $\begin{array}{l}\text { Schechter- } \\
\text { Perkins., et } \\
\text { al. } 2011\end{array}$ \\
\hline $\begin{array}{l}\text { United States } \\
\text { (10 EDs nation- } \\
\text { wide) }\end{array}$ & $2010-2012$ & $\begin{array}{l}\text { ED patients with closed skin abscess } \\
\qquad(\mathrm{n}=147) \\
\text { ED patients with no abscess ( } \mathrm{n}=147) \\
\text { Nasal samples }\end{array}$ & $\begin{array}{l}\text { See patient type } \\
\text { column }\end{array}$ & \begin{tabular}{|}
$53.1 \%$ (ab- \\
scess patients) \\
$38.8 \%$ (no \\
abscess)
\end{tabular} & \begin{tabular}{|c|}
$25.2 \%$ (abscess \\
patients) \\
$9.5 \%$ (no abscess)
\end{tabular} & \begin{tabular}{|c|}
$47.4 \%$ (abscess \\
patients) \\
$24.5 \%$ (no abscess)
\end{tabular} & $\begin{array}{l}\text { Albrecht., et } \\
\text { al. } 2015\end{array}$ \\
\hline $\begin{array}{l}\text { United States } \\
\text { (Virginia) }\end{array}$ & $2008-2010$ & $\begin{array}{l}\text { Patients attending student and ambula- } \\
\text { tory clinics } \\
\text { Nasal samples }\end{array}$ & 1000 & $45.8 \%$ & $1.6 \%$ & $3.5 \%$ & $\begin{array}{l}\text { Bearman., et } \\
\text { al. } 2010\end{array}$ \\
\hline $\begin{array}{l}\text { United States } \\
\text { (18 ICUs nation- } \\
\text { wide }\end{array}$ & $\begin{array}{l}\text { March-August } \\
2006\end{array}$ & $\begin{array}{l}\text { Patients on admission to ICU (STAR*ICU } \\
\text { trial) } \\
\text { Nasal samples }\end{array}$ & 5512 & Not specified & $11.3 \%$ & Not specified & $\begin{array}{l}\text { Nair., et al. } \\
2011\end{array}$ \\
\hline $\begin{array}{l}\text { United States } \\
\text { (New York met- } \\
\text { ropolitan area) }\end{array}$ & $\begin{array}{c}\text { November } \\
\text { 2011-March } 2013\end{array}$ & $\begin{array}{c}\text { Patients attending community health clin- } \\
\text { ics for SSTIs } \\
\text { Nasal samples }\end{array}$ & 129 & $48.8 \%$ & $12.4 \%$ & $25.4 \%$ & $\begin{array}{c}\text { Pardos de la } \\
\text { Gandara., et } \\
\text { al. } 2015\end{array}$ \\
\hline
\end{tabular}

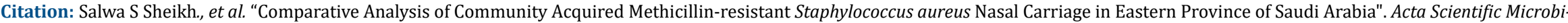
ology 5.1 (2022): 80-88. 


\begin{tabular}{|c|c|c|c|c|c|c|c|}
\hline Egypt & $\begin{array}{l}\text { July-October } \\
2011\end{array}$ & $\begin{array}{l}\text { Primary care centre outpatients } \\
\text { Nasal samples }\end{array}$ & 103 & $52.4 \%$ & $32.0 \%$ & $52.0 \%$ & $\begin{array}{l}\text { Abou-Shady., } \\
\text { et al. } 2015\end{array}$ \\
\hline Tanzania & $\begin{array}{l}\text { March-August } \\
\quad 2015\end{array}$ & $\begin{array}{l}\text { Patients immediately on admission to } \\
\text { regional hospitals } \\
\text { Nasal samples }\end{array}$ & 258 & $34.5 \%$ & $8.5 \%$ & $24.7 \%$ & $\begin{array}{l}\text { Joachim., et } \\
\text { al. } 2017\end{array}$ \\
\hline Brazil & $\begin{array}{l}\text { January to April } \\
2017\end{array}$ & $\begin{array}{l}\text { Teaching hospital outpatients } \\
\text { Nasal samples }\end{array}$ & 300 & $42.3 \%$ & $\begin{array}{l}2.3 \% \text { (communi- } \\
\text { ty-acquired) }\end{array}$ & $\begin{array}{l}5.5 \% \text { (community- } \\
\text { acquired) }\end{array}$ & $\begin{array}{l}\text { Bes., et al. } \\
\quad 2018\end{array}$ \\
\hline Brazil & $\begin{array}{l}\text { March 2012- } \\
\text { March } 2013\end{array}$ & $\begin{array}{c}\text { Teaching hospital patients immediately } \\
\text { on admission } \\
\text { Nasal samples }\end{array}$ & 702 & $25.6 \%$ & $3 \%$ & $11.7 \%$ & $\begin{array}{l}\text { Cavalcante., } \\
\text { et al. } 2017\end{array}$ \\
\hline India & $\begin{array}{l}\text { April 2012-May } \\
2013 \\
\end{array}$ & $\begin{array}{l}\text { Patients attending tertiary care centre } \\
\text { Nasal samples }\end{array}$ & 683 & Not specified & $2.3 \%$ & Not specified & $\begin{array}{l}\text { George., et al. } \\
2016\end{array}$ \\
\hline \begin{tabular}{|c|} 
Europe (13 ICUs \\
in 8 countries) \\
\end{tabular} & $\begin{array}{l}\text { May 2008-April } \\
2011 \\
\end{array}$ & $\begin{array}{l}\text { Patients on ICU admission } \\
\text { Nasal and wound swabs }\end{array}$ & 8519 & Not specified & $\begin{array}{l}3.9 \% \text { (range } 1 \% \\
\text { to } 7 \% \text { ) }\end{array}$ & Not determined & $\begin{array}{l}\text { Hetem., et al. } \\
\quad 2016\end{array}$ \\
\hline $\begin{array}{l}\text { Europe (GP } \\
\text { surgeries in } 9 \\
\text { countries) }\end{array}$ & $\begin{array}{l}\text { November } \\
\text { 2010-August } \\
2011\end{array}$ & Patients attending GP surgeries & 32206 & $21.6 \%$ & $\begin{array}{l}0.3 \% \text { (range } 0 \% \\
\text { to } 0.4 \% \text { ) }\end{array}$ & $\begin{array}{c}1.3 \% \text { (range } 0 \% \text { to } \\
2.1 \%)\end{array}$ & $\begin{array}{l}\text { Den Heijer., } \\
\text { et al. } 2016\end{array}$ \\
\hline United Kingdom & 2012 & $\begin{array}{c}\text { NHS general practice patient cross- } \\
\text { section } \\
\text { Nasal samples }\end{array}$ & 530 & $28 \%$ & $1.9 \%$ & $6.8 \%$ & $\begin{array}{l}\text { Gamblin et } \\
\text { al. } 2013\end{array}$ \\
\hline
\end{tabular}

Table 1: Studies on CA-MRSA nasal carriage rates in Saudi Arabia and worldwide.

ED: Emergency Department; ICU: Intensive Care Unit; SSTI: Skin and Soft Tissue Infection; NHS: National Health Service.

The USA average of MRSA nasal carriage among the whole community according to the Center for Disease Control and Prevention (CDC) is approximately 2\% (https:// www.cdc.gov/mrsa/healthcare/index.html). Results from six papers covering a wide range of states in the USA suggest that the mean CA-MRSA nasal carriage is $10.6 \pm 7.1 \%$ among outpatients and patients upon admission to healthcare facilities [15-20] (Table 1). There is considerable geographical heterogeneity in carriage rates within the USA (Table 1).

Outpatients and patients attending at primary and tertiary healthcare centres have also been recently studied in other countries. In two recent studies from teaching hospitals in Brazil, CA-MRSA nasal carriage levels of $2.3 \%$ and $3 \%$ (mean $2.7 \pm 0.4 \%$ ) (5.5\% and $11.7 \%$ of $S$. aureus levels respectively) were observed (Table 1) [21, 22]. Levels in studies from African countries were higher; Tanzania had a CA-MRSA nasal carrier rate of $8.5 \%$ (24.7\% of S. aureus) in a study of patients admitted to a regional hospital, while Egypt had a CA-MRSA nasal carrier rate of $32.0 \%$ (52.0\% of S. aureus) in a study on primary care center outpatients (Table 1) [6,23]. A large recent study on patients on ICU admission carried out in thirteen ICUs in eight countries in Europe indicated a mean CA-MRSA nasal carriage rate of 3.9\%, with a range of 1-7\%, while another large European study on patients attending GP surgeries in nine countries indicated a lower level of $0.3 \%$ CA-MRSA nasal carriage (range $0 \%$ to $0.4 \%$ ) $[4,24]$. Within the study by Den Heijer., et al. (2016) [24], patients recruited within the UK had a mean CA-MRSA nasal carriage rate of $0.4 \%$, whereas in another cross-sectional study of 530 NHS general practice patients a figure of $1.9 \%$ (6.8\% of S. aureus samples) was obtained, indicating the variability across studies [24,25]. For a study of patients attending a tertiary care center in India, the CA-MRSA nasal carriage rate was 2.3\% [26]. Figure 3 summarizes mean CA-MRSA nasal carriage rates across a range of countries, including Saudi Arabia, with percentage of $S$. aureus included where it was determined.

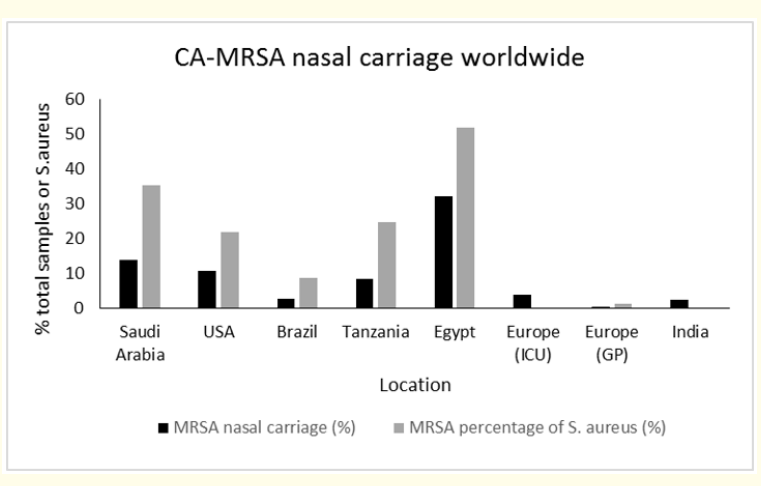

Figure 3: CA-MRSA nasal carrier rates worldwide. 


\section{Discussion and Conclusion}

Approximately one third of people carry $S$. aureus in their nasal cavity. MRSA infections first emerged in the 1960s and were confined mostly to healthcare settings, presenting as a hospital acquired infection [27]. By the 1980s, reports emerged of MRSA acquired in the community outside healthcare facilities, becoming steadily more frequent from the 1990s [27]. While CA-MRSA tends to be associated with less serious conditions than HA-MRSA, primarily SSTIs, these conditions can be chronic or recurrent and if neglected they can lead to more serious conditions including necrotizing pneumonia, sepsis, and osteomyelitis [27]. In many parts of the world CA-MRSA has emerged as the leading cause of SSTIs in the community [28]. There have been few studies examining CA-MRSA colonization prevalence either in Saudi Arabia generally, or the Eastern Province in particular. MRSA colonization is an important risk factor for subsequent MRSA infection and its transmission. Anterior nares are the primary site of colonization; although MRSA can colonize other areas of the body such as the throat and groin [29]. In addition, open-skin wounds and device sites are important colonization sites for MRSA [30]. Thus, analysis of the nasal carriage levels of CA-MRSA in the Eastern Province, and comparison to other regions of Saudi Arabia, as well as to the USA and other countries, would be helpful in identifying the scale of the problem and addressing shortcomings in infection prevention and control in the Saudi Arabia healthcare system and workplaces.

Global CA-MRSA outbreaks have been reported from multiple countries including the USA, New Zealand, and Saudi Arabia, more commonly in groups such as impoverished adults in medically underprivileged areas, players of team sports, incarcerated persons, military recruits, intravenous drug abusers, postpartum women, men who have sex with men, the elderly, neonates, children in daycare centers and those with history of colonization or recent infection with CA-MRSA strains $[27,31]$. These groups are more subject to combinations of risk factors including close contact, crowded living conditions, skin abrasions, poor hygiene and sharing of equipment or needles. Infections due to MRSA have become a burden on healthcare resources. Studies show that although total hospital-onset MRSA bloodstream infection rates may remain relatively stable, infections by CA-MRSA are responsible for an increasing proportion of cases of MRSA infections (from 24\% to 49\%) [32].

In this study, we used results from more than 3000 patients to determine CA-MRSA carriage rates in outpatients at Johns Hopkins
Aramco Healthcare Center (JHAH) in Dhahran in the Eastern Province of Saudi Arabia. An earlier study in the Eastern Province was carried out on 600 patients admitted to King Fahad Hospital in $\mathrm{Al}$ Hofuf between January and March 2004. Results indicated an overall CA-MRSA nasal carrier rate of $1.2 \%$, or $5.7 \%$ of $S$. aureus samples [33]. Our study therefore indicated a higher CA-MRSA nasal carrier rate for patients attending our institution between January 2013 and December 2014. This increase in CA-MRSA carriage rates within the Eastern Province is consistent with indications from a previous study from our institution which showed that CA-MRSA rates increased among inpatients admitted between 2004 and 2009 while HA-MRSA cases decreased [34]. The increase in CAMRSA levels compared to HA-MRSA levels is also consistent with experience in other countries, including the USA and China [35,36]. Our measured CA-MRSA levels were lower than those observed in smaller studies from Saudi Arabia on patients attending healthcare facilities in north-central (Buradiyah) or central (Shaqra), but comparable to levels observed among pediatric outpatients in a recent study from Riyadh [6-8].

Geographic heterogeneity in CA-MRSA prevalence and its occurrence relative to HA-MRSA is a phenomenon also observed in other countries. For example, in the USA, a study of blood cultures from bacteremia patients from five academic medical centers revealed that while CA-MRSA expression levels relative to HA-MRSA stayed stable in three centers between 2008 and 2011, it increased threefold in one center and declined in another center [37]. The overall MRSA carrier rate in the United States is $2 \%$ as reported by the CDC, although there is no distinction made between HA-MRSA and CA-MRSA in this figure. Prevalence levels also vary between countries in Europe [4,38]. Within healthy European populations, carriage levels have been shown to vary from $0.3 \%$ in healthy children in Hungary to $8.8 \%$ of healthy adults in Malta [39,40]. There is also genotypic diversity in CA-MRSA expression worldwide. In the USA, the USA300 type is predominant while in Europe and Asia there is clonal heterogeneity between countries, including in Saudi Arabia $[4,11,38,41]$.

Recent studies have indicated an overall decline in both total MRSA and in CA-MRSA levels, for example in hospitals in the USA, however the decline in prevalence varies geographically $[42,43]$. Moreover, while hospitalization related to MRSA-expressing SSTIs declined in the USA between 2010 and 2014, there was no real change in invasive infection levels [35]. Our study results suggest

Citation: Salwa S Sheikh., et al. "Comparative Analysis of Community Acquired Methicillin-resistant Staphylococcus aureus Nasal Carriage in Eastern Province of Saudi Arabia". Acta Scientific Microbiology 5.1 (2022): 80-88. 
that in Saudi Arabia the CA-MRSA nasal carriage levels are increasing and that there is variability between regions. Our examination of the literature on CA-MRSA nasal carriage among outpatients and patients upon admission to healthcare facilities in other countries showed that levels in Saudi Arabia are higher than in many other countries including the USA and most European countries. These high levels are occurring in a context where Saudi Arabia is ranked at 26 in terms of its healthcare system in the world by the World Health Organization (WHO) [www.who.int/healthinfo/paper30. pdf]. Carrier levels of CA-MRSA among patient groups in northcentral (Buradiyah) and central (Shaqra) were alarmingly high at $25.2 \%$ and $21.8 \%$ respectively [6,7]. Meanwhile, a recent study from the King Abdulaziz University Hospital in Jeddah in western Saudi Arabia showed that CA-MRSA was present in $34.8 \%$ of 89 clinical isolates expressing S. aureus [11]. A study on S. aureus clinical isolates from a hospital in Makkah City, also in western Saudi Arabia, similarly indicated that CA-MRSA was present in $31.5 \%$ of S. aureus isolates [9]. The western region of Saudi Arabia is subject to an influx of millions of pilgrims each year for the Hajj and Umrah pilgrimages. According to the Saudi government, nearly two million individuals performed Hajj in 2016 [44]. Many of these are from countries of with limited healthcare infrastructure. The western region is therefore potentially most vulnerable to CA-MRSA outbreaks and dissemination of a wide variety of CA-MRSA strains. Efforts to address the threat of CA-MRSA arising in the community in Saudi Arabia need to take this into account. Other factors to be considered include poor infection control method implementation in the community that aim at reducing the transmission of diseases and thus theoretically reduce the overall carrier rate of CA-MRSA. Moreover, there may be many hospital workers who carry MRSA and act as reservoirs for the pathogen; when these individuals mix with the general public, this could increase the prevalence of MRSA in that community.

Limitations of our study include the fact that we did not carry out genetic analysis of the samples to determine SCCmec type. Also, comparisons with the literature are complicated by factors such as lack of uniformity in sample collection and analysis methods and in selection of patients. Nevertheless, our study expands the information available on CA-MRSA carrier levels in Saudi Arabia and should help inform public health strategies in combating this issue.

\section{Ethical Approval}

The study was approved by the Institutional Review Board (IRB) of Johns Hopkins Aramco Healthcare

\section{Competing Interests}

The authors declare no competing interests.

\section{Authors' contributions}

All authors have read and agreed to the final version of this manuscript and have equally contributed to its content and to the management of the case.

\section{Conflict of Interest}

None declared.

\section{Research Funding}

None declared.

\section{Bibliography}

1. "Methicillin-Resistant Staphylococcus Aureus (MRSA)". Centers for Disease Control and Prevention, Centers for Disease Control and Prevention, 6 June (2018).

2. Naimi TS., et al. "Comparison of community- and health careassociated methicillin-resistant Staphylococcus aureus infection". Journal of the American Medical Association 290 (2003): 2976-2984.

3. Shore AC and Coleman DC. "Staphylococcal cassette chromosome mec: recent advances and new insights". International Journal of Medical Microbiology 303 (2013): 350-359.

4. Hetem DJ., et al. "Molecular epidemiology of MRSA in 13 ICUs from eight European countries". Journal of Antimicrobial Chemotherapy 71.1 (2016): 45-52.

5. Rabaan AA and Bazzi AM. "Variation in MRSA identification results from different generations of Xpert MRSA real-time PCR testing kits from nasal swabs". Journal of Infection and Public Health 10 (2017): 799-802.

6. Abou Shady HM., et al. "Staphylococcus aureus nasal carriage among outpatients attending primary health care centers: a comparative study of two cities in Saudi Arabia and Egypt". Brazilian Journal of Infectious Diseases 19 (2015): 68-76 
7. Alhussaini MS. "Methicillin-resistant Staphylococcus aureus nasal carriage among patients admitted at Shaqra General Hospital in Saudi Arabia". Pakistan Journal of Biological Sciences 19 (2016): 233-238.

8. Alaklobi F., et al. "The prevalence of community-associated methicillin-resistant Staphylococcus aureus among outpatient children in a tertiary hospital: a prospective observational study in Riyadh, Saudi Arabia". International Journal of Pediatrics and Adolescent Medicine 2 (2015): 136-140.

9. El Amin NM and Faidah HS. "Methicillin-resistant Staphylococcus aureus in the western region of Saudi Arabia: prevalence and antibiotic susceptibility pattern". Annals of Saudi Medicine 32 (2012): 513-516.

10. Asghar AH. "Molecular characterization of methicillin-resistant Staphylococcus aureus isolated from tertiary care hospitals". Pakistan Journal of Medical Sciences 3 (2014): 698-702.

11. Al-Zahrani I., et al. "Impact of mass migrations on the clonal variation of clinical Staphylococcus aureus strains isolated from the Western region of Saudi Arabia". Journal of Infection and Public Health (2018).

12. Sarkar A., et al. "Antimicrobial resistance and virulence markers in methicillin sensitive Staphylococcus aureus isolates associated with nasal colonization". Microbial Pathogenesis 93 (2016): 8-12.

13. Zakai SA. "Prevalence of methicillin-resistant Staphylococcus aureus nasal colonization among medical students in Jeddah, Saudi Arabia". Saudi Medical Journal 36 (2015): 807-812.

14. Eed EM., et al. "Molecular characterisation of Panton-Valentine leucocidin-producing methicillin-resistant Staphylococcus aureus clones isolated from the main hospitals in Taif, KSA". Indian Journal of Medical Microbiology 34 (2016): 476-482.

15. Marzec NS and Bessesen MT. "Risk and outcomes of methicillin-resistant Staphylococcus aureus (MRSA) bacteremia among patients admitted with and without MRSA nares colonization". American Journal of Infection Control 44 (2016): 405-408.

16. Schechter-Perkins E., et al. "Prevalence and predictors of nasal and extranasal staphylococcal colonization in patients presenting to the emergency department". Annals of Emergency Medicine 57 (2011): 492-499.
17. Albrecht VS., et al. "Staphylococcus aureus colonization and strain type at various body sites among patients with a closed abscess and uninfected controls at U.S. emergency departments". Journal of Clinical Microbiology 53 (2015): 3478-3484.

18. Bearman GML., et al. "Nasal carriage of inducible dormant and community-associated methicillin-resistant Staphylococcus aureus in an ambulatory population of predominantly university students". International Journal of Infectious Diseases 14 (2010): e18-e24.

19. Nair N., et al. "Molecular epidemiology of methicillin-resistant Staphylococcus aureus (MRSA) among patients admitted to adult intensive care units: the STAR*ICU trial". Infection Control and Hospital Epidemiology 32 (2011): 1057-1063.

20. Pardos de la Gandara., et al. "Molecular Types of methicillinresistant Staphylococcus aureus and methicillin-sensitive $S$. aureus strains causing skin and soft tissue infections and nasal colonization, identified in community health centers in New York City". Journal of Clinical Microbiology 53 (2015): 26482658.

21. Bes TM., et al. "Prevalence of methicillin-resistant Staphylococcus aureus colonization in individuals from the community in the city of Sao Paulo, Brazil". Revista do Instituto de Medicina Tropical de São Paulo 60 (2018): 1.

22. Cavalcante FS., et al. "Characteristics of methicillin-resistant Staphylococcus aureus in patients on admission to a teaching hospital in Rio de Janeiro, Brazil". American Journal of Infection Control 45 (2017): 1190-1193.

23. Joachim A., et al. "Prevalence of methicillin-resistant Staphylococcus aureus carriage on admission among patients attending regional hospitals in Dar es Salaam, Tanzania”. BMC Research Notes 10 (2017): 417.

24. den Heijer CDJ., et al. "Prevalence and resistance of commensal Staphylococcus aureus, including meticillin-resistant S aureus, in nine European countries: a cross-sectional study". The Lancet Infectious Diseases 13 (2013): 409-415.

25. Gamblin J., et al. "Nasal self-swabbing for estimating the prevalence of Staphylococcus aureus in the community". Journal of Medical Microbiology 62 (2013): 437-440. 
26. George K., et al. "Prevalence of MRSA nasal carriage in patients admitted to a tertiary care hospital in Southern India". Journal of Clinical and Diagnostic Research 10 (2016): DC11-DC13.

27. Kale $\mathrm{P}$ and Dhawan B. "The changing face of community-acquired methicillin-resistant Staphylococcus aureus". Indian Journal of Medical Microbiology 34 (2016): 275-285.

28. Sader HS., et al. "Frequency and antimicrobial susceptibility of bacterial isolates from patients hospitalised with communityacquired skin and skin structure infection in Europe, Asia, and Latin America". Journal of Global Antimicrobial Resistance (2018).

29. Walrath JJ., et al. "The prevalence of MRSA nasal carriage in preoperative pediatric orthopaedic patients". Advances in Orthopedics 2016 (2016): 5646529.

30. Almeida GCM., et al. "Prevalence and factors associated with wound colonization by Staphylococcus spp. and Staphylococcus aureus in hospitalized patients in inland northeastern Brazil: a cross-sectional study". BMC Infectious Diseases 14 (2014): 328.

31. Dagunton N., et al. "MRSA outbreak at neonatal ICU in Saudi Arabia". Antimicrobial Resistance and Infection Control 4 (2015): P225.

32. Popovich KJ., et al. "Are community-associated methicillin-resistant Staphylococcus aureus (MRSA) strains replacing traditional nosocomial MRSA strains?" Clinical Infectious Diseases 46 (2008): 787-794.

33. Panhotra BR., et al. "Prevalence of methicillin-resistant and methicillin-sensitive Staphylococcus aureus nasal colonization among patients at the time of admission to the hospital". Annals of Saudi Medicine 25 (2005): 304-308.

34. Khanfar H., et al. "Methicillin-resistant Staphylococcus aureus transmission in a low-prevalence healthcare setting". Journal of Infection and Public Health 5 (2012): 311-316.

35. Klein EY., et al. "Trends in methicillin-resistant Staphylococcus aureus hospitalizations in the United States, 2010-2014". Clinical Infectious Diseases 65 (2017): 1921-1923.

36. Li M., et al. "Increased community-associated infections caused by Panton-Valentine leukocidin-negative MRSA, Shanghai, 2005-2014". Emerging Infectious Diseases 22 (2016): 1988-1991.
37. David MZ., et al. "Staphylococcus aureus bacteremia at 5 US academic medical centers, 2008-2011: significant geographic variation in community-onset infections". Clinical Infectious Diseases 59 (2014): 798-807.

38. Bouchiat C., et al. "MRSA infections among patients in the emergency department: a European multicentre study". Journal of Antimicrobial Chemotherapy 72 (2017): 372-375.

39. Laub K., et al. "High prevalence of Staphylococcus aureus nasal carriage among children in Szolnok, Hungary". Acta Microbiologica et Immunologica Hungarica 65 (2018): 59-72.

40. Scerri J., et al. "Prevalence and characteristics of community carriage of methicillin-resistant Staphylococcus aureus in Malta". Journal of Epidemiology and Global Health 3 (2013): 165173.

41. Chuang Y and Huang Y. "Molecular epidemiology of community-associated meticillin-resistant Staphylococcus aureus in Asia". The Lancet. Infectious Diseases 13 (2013): 698-708.

42. Dantes R., et al. "National burden of invasive methicillin-resistant Staphylococcus aureus infections, United States, 2011". Journal of the American Medical Association Internal Medicine 173 (2013): 1970-1978.

43. Hultén KG., et al. "Analysis of invasive community-acquired methicillin-susceptible Staphylococcus aureus Infections during a period of declining community acquired methicillin-resistant Staphylococcus aureus infections at a large children's hospital". Pediatric Infectious Disease Journal 37 (2018): 235241.

44. General Authority for Statistics, Saudi Arabia. Hajj statistics (2019).

\section{Assets from publication with us}

- Prompt Acknowledgement after receiving the article

- Thorough Double blinded peer review

- Rapid Publication

- Issue of Publication Certificate

- High visibility of your Published work

Website: www.actascientific.com/

Submit Article: www.actascientific.com/submission.php Emaill us: editor@actascientific.com

Contact us: +919182824667 